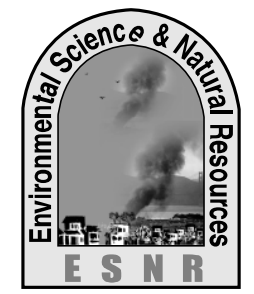

\title{
Growth Yield and Yield Attributes of Tomato (Lycopersicon esculentum Mill.) as Influenced by Indole Acetic Acid
}

\author{
A. M. Khaled, S. Sikder*, M. R. Islam, M. A. Hasan and M. M. Bahadur \\ Department of Crop Physiology and Ecology \\ Hajee Mohammad Danesh Science and Technology University, Dinajpur \\ *Corresponding author: srisikder@gmail.com
}

\begin{abstract}
The experiment was conducted at research field and laboratory of the Department of Crop Physiology and Ecology, Hajee Mohammad Danesh Science and Technology University, Dinajpur, Bangladesh during the period of December 2013 to April 2014. The experiment was laid out in two factors randomized complete block design with three replications including three concentrations of Indole Acetic Acid (0,100 and $200 \mathrm{ppm}$ ) and three tomato varieties (BARI tomato 7, Manik and Ratan). Plant height, number of leaves and number of branches, days required for first flower initiation, days required for $50 \%$ flowering, days required for fruit setting, fruit cluster plant ${ }^{-1}$, fruit plant ${ }^{-1}$, weight tomato ${ }^{-1}$, yield plant ${ }^{-1}$, yield plot $^{-1}$ and yield hectare $^{-1}$ were significant influenced by the combined application of IAA and varieties of tomato. BARI Tomato-7 had the highest fruit yield with 100 ppm IAA and the lowest yield was observed in Ratan with 0 ppm IAA. IAA treated plots showed better performance for growth parameters and yield compared to control condition and 100 ppm IAA was more suitable than the $200 \mathrm{ppm}$ IAA for higher yield of tomato cultivation. Among the treatment combinations, BARI Tomato-7 with $100 \mathrm{ppm}$ IAA was superior, Ratan with 0 ppm IAA was inferior and BARI Tomato-7 with 200 ppm IAA, Manik with 200 ppm IAA and Ratan with 200 ppm IAA treated plots showed the intermediate results for yield and yield components.
\end{abstract}

Key words: Growth, Indole acetic acid, Tomato, Yield

\section{Introduction}

Vegetable is an important component of a balanced human diet. Among the vegetables tomato (Lycopersicon esculentum Mill.) is very important and widely grown not only in Bangladesh but also in many countries of the world for its taste and nutritional status. Application of growth regulator has good management effect on growth and yield of tomato. Flower and fruit abortion are common phenomenon in tomato and a large proportion of tomato reproductive structures abscise before reaching maturity, which is the primary cause of lowering yield in summer season (Mondal et al. 2011). Hormones regulate abscission process and synthetic hormones may reduce abscission and ultimately increase in yield of soybean (Nahar and Ikeda, 2002) and tomato (Abdel et al. 1996). Plant growth regulators have been reported to improve germination, growth, fruit set and seed yields and yield quality (Saimbhi, 1993). Application of plant growth regulator seems to be one of the important practices in view of convenience, cost and labour efficiency. Among the growth promoters, Indole Acetic Acid (IAA) plays an important role to improving the plant growth and yield of vegetable crops. IAA affects the physiological processes, hastens maturity and improving the quality of fruits. Indole acetic acid (IAA) is the most abundant naturally occurring plant hormone, well known for its regulating function in plant growth and development (Rout 2006). Indole acetic acid is a type of auxin that stimulates growth through cell elongation and lateral root formation which probably support more absorption of minerals (Egamberdieva 2009). Research work with IAA on growth, yield attributes and fruit yield of tomato is scanty. Therefore, considering the above facts, the present study was taken to study the effect of IAA on growth, yield and yield attributes of tomato under Bangladesh conditions.

\section{Materials and Methods}

The experiment was conducted at research field and laboratory of the Department of Crop Physiology and Ecology, Hajee Mohammad Danesh Science and Technology University, Dinajpur, Bangladesh during the period of December 2013 to April 2014. The experiment was laid out in two factors randomized complete block design with three replications including three concentrations of Indole Acetic Acid (0, 100 and $200 \mathrm{ppm}$ ) and three tomato varieties (BARI tomato 7, Manik and Ratan). Each replication then divided into nine unit plot of $2.0 \mathrm{~m} \times 2.0 \mathrm{~m}$ sizes. The distance between block to block was $1.5 \mathrm{~m}$ and plot to plot was $0.5 \mathrm{~m}$. The plots were fertilized with the recommended dose of compost, urea, TSP, MoP, Gypsum, Zinc sulphate and Boric acid (6000, 250, $175,200,75,8$ and $8 \mathrm{~kg} \mathrm{ha}^{-1}$, respectively). Twenty days old seedlings of tomato were transplanted in line as per treatment on 6 December 2013 by hand uniformly. The spacing maintained between lines to line was $50 \mathrm{~cm}$ and plant to plant was $40 \mathrm{~cm}$. Intercultural operations like weeding, irrigation etc. were done as per need. The IAA solutions of 0,100 and $200 \mathrm{ppm}$ concentrations were prepared by dissolving 0,100 and $200 \mathrm{mg}$ of IAA in $10 \mathrm{ml}$ methanol prior to dilution with distilled water. Then distilled water was added to make the volume 1 litre to get 0,100 and $200 \mathrm{ppm}$ concentrated IAA solution, respectively. The foliar spraying was done at 30 DAS with the help of a hand sprayer until all leaves were completed wetted. The crop was harvested at maturity for three times. Plant height, number of leaves, number of branches, first flower 
initiation date, fifty percent flowering date, date of fruit setting, fruits cluster plant ${ }^{-1}$, fruits cluster ${ }^{-1}$, fruits plant ${ }^{-1}$, length of fruit, diameter of fruit, weight tomato ${ }^{-1}$,and yield of tomato were taken properly. All the recorded data was statistically analyzed following the ANOVA technique and the significance of mean differences were adjusted by Duncan's Multiple Range Test, DMRT (Gomez and Gomez 1984) with the help of computer package M-STAT.

\section{Results and Discussion}

\section{Plant height}

The interaction effect of IAA and tomato varieties on plant height of tomato at different days after planting (DAP) was significant. The influence of IAA on plant height of tomato varieties at different days after planting is shown in Table 1. From the results, it was found that plant height was increased with the increment of time and concentration of indole acetic acid (IAA). At 15 DAP the highest plant height was showed by BARI Tomato-7 with 200 ppm IAA $(26.17 \mathrm{~cm})$ which was at par with BARI Tomato-7 with 100 ppm IAA $(26.00 \mathrm{~cm})$, whereas the lowest plant height was found in the combination of Manik $\times 0$ ppm IAA $(23.42 \mathrm{~cm})$ which was statistically similar with Manik $\times 200$ ppm IAA and Manik $\times 100$ ppm IAA (23.45 and $23.55 \mathrm{~cm}$, respectively). At $30 \mathrm{DAP}$ the highest plant height was attained by BARI Tomato-7 with 100 ppm IAA $(47.83 \mathrm{~cm})$ followed by BARI Tomato-7 with 200 ppm IAA and Manik with 100 ppm IAA (46.53 and $43.80 \mathrm{~cm}$, respectively), whereas the lowest plant height was found in Ratan at control condition $(37.55 \mathrm{~cm})$ followed by Manik $\times 0$ ppm IAA $(39.85 \mathrm{~cm})$. At 45 DAP the highest plant height was produced by BARI Tomato-7 with 100 ppm IAA $(68.33 \mathrm{~cm})$ followed by BARI Tomato-7 $\times 200$ ppm IAA, Manik $\times 100$ ppm IAA and Manik $\times 200$ ppm IAA $(65.67,65.30$ and 65.20 $\mathrm{cm}$, respectively), whereas, the lowest plant height was found in Manik $(52.03 \mathrm{~cm})$ at control followed by Ratan with 0 ppm IAA $(52.18 \mathrm{~cm})$. At 60 DAP the highest plant height was attained by Ratan with 100 ppm IAA $(76.77 \mathrm{~cm})$ followed by BARI Tomato 7 with 100 ppm IAA and Ratan with 200 ppm IAA (76.50 and $76.15 \mathrm{~cm}$, respectively), whereas at control condition the lowest plant height was found in Ratan $(60.25 \mathrm{~cm})$ which was at par with Manik $(60.42 \mathrm{~cm})$. At 70 DAP the highest plant height was produced by BARI Tomato-7 with 100 ppm IAA $(78.80 \mathrm{~cm})$ followed by Ratan $\times 100$ ppm IAA and Ratan $\times 200$ ppm IAA (77.47 and $76.47 \mathrm{~cm}$, respectively), whereas, the lowest plant height was also found in Ratan $(60.53, \mathrm{~cm})$ at control condition which was followed by BARI Tomato-7 and Manik with 0 ppm IAA (62.33 and $63.63 \mathrm{~cm}$, respectively). Application of auxin increased plant height at different crops also reported. Ray (2014) described that application of IAA significantly increased the height of mustard plant. Prasad et al. (2013) was found that there was a linear increase in growth parameters like plant height and number of branches per plant with increasing level of $\mathrm{GA}_{3}$ and NAA.

Table 1. Interaction effect of IAA and varieties of tomato on plant height at different days after planting (DAP)

\begin{tabular}{|c|c|c|c|c|c|c|}
\hline \multirow{2}{*}{ Variety } & Levels of & \multicolumn{5}{|c|}{ Plant height $(\mathrm{cm})$} \\
\cline { 2 - 7 } & IAA (ppm) & $15 \mathrm{DAP}$ & $30 \mathrm{DAP}$ & $45 \mathrm{DAP}$ & $60 \mathrm{DAP}$ & $70 \mathrm{DAP}$ \\
\hline \multirow{3}{*}{ BARI Tomato 7 } & 0 & $25.67 \mathrm{ab}$ & $40.83 \mathrm{fg}$ & $53.67 \mathrm{~d}$ & $61.83 \mathrm{e}$ & $62.33 \mathrm{c}$ \\
\cline { 2 - 7 } & 100 & $26.00 \mathrm{a}$ & $47.83 \mathrm{a}$ & $68.33 \mathrm{a}$ & $76.50 \mathrm{ab}$ & $78.80 \mathrm{a}$ \\
\cline { 2 - 7 } & 200 & $26.17 \mathrm{a}$ & $46.53 \mathrm{~b}$ & $65.67 \mathrm{~b}$ & $73.50 \mathrm{~d}$ & $74.70 \mathrm{~b}$ \\
\hline \multirow{3}{*}{ Manik } & 0 & $23.42 \mathrm{~d}$ & $39.85 \mathrm{~g}$ & $52.03 \mathrm{e}$ & $60.42 \mathrm{f}$ & $63.63 \mathrm{c}$ \\
\cline { 2 - 7 } & 100 & $23.55 \mathrm{~d}$ & $43.80 \mathrm{c}$ & $65.30 \mathrm{~b}$ & $75.53 \mathrm{bc}$ & $75.82 \mathrm{ab}$ \\
\cline { 2 - 7 } & 200 & $23.45 \mathrm{~d}$ & $42.78 \mathrm{~cd}$ & $65.20 \mathrm{~b}$ & $75.07 \mathrm{c}$ & $75.47 \mathrm{ab}$ \\
\hline \multirow{3}{*}{ Ratan } & 0 & $25.13 \mathrm{abc}$ & $37.55 \mathrm{~h}$ & $52.18 \mathrm{e}$ & $60.25 \mathrm{f}$ & $60.53 \mathrm{c}$ \\
\cline { 2 - 7 } & 100 & $24.40 \mathrm{~cd}$ & $41.23 \mathrm{ef}$ & $63.77 \mathrm{c}$ & $76.77 \mathrm{a}$ & $77.47 \mathrm{ab}$ \\
\hline & 200 & $24.77 \mathrm{bc}$ & $42.07 \mathrm{de}$ & $63.25 \mathrm{c}$ & $76.15 \mathrm{ab}$ & $76.47 \mathrm{ab}$ \\
\hline
\end{tabular}

Values followed by the different letter(s) are significantly different from each other by DMRT at 5\% level

\section{Number of leaves plant ${ }^{-1}$}

The interaction effect of IAA and tomato varieties on number of leaves of tomato at different DAP was significant. The effect of IAA on leaf number of tomato varieties at different days after planting is presented in Table 2. From the results, it was found that numbers of leaves were increased with the advancement of growing period and concentration of indole acetic acid (IAA). At 15 DAP the maximum number of leaves (16.33) was produced by BARI Tomato-7 with 200 ppm IAA and Manik with 100 and 200 ppm IAA levels, whereas the lowest number of leaves (14.00) was found by Ratan with 100 and 200 ppm IAA levels. At 30 DAP the highest number of leaves was produced by Manik (41.67) with 200 ppm IAA treated plots followed by Ratan BARI $\times 200 \mathrm{ppm}$ IAA (41.33) and BARI Tomato-7×200 ppm IAA (40.67) , whereas the lowest number of leaves (31.67) was found by Ratan and BARI Tomato-7 at control condition. At 45, 60 and 70 DAP variety Manik produced highest number of leaves (71.67, 73.67 and 74.33, respectively) in 100 ppm IAA treated plots which was followed by BARI 
Tomato-7 with 100 ppm IAA $(70.33,72.00$ and 73.00, respectively), whereas BARI Tomato-7 was produced lowest number of leaves under control condition (59.00, 60.67 and 61.33, respectively).
Gaba et al. (1999) found similar trend of result in tomato. They observed that number of leaves increased with the application of plant growth regulators.

Table 2. Interaction effect of IAA and varieties of tomato on number of leaves at different days after planting (DAP)

\begin{tabular}{|c|c|c|c|c|c|c|}
\hline \multirow{2}{*}{ Variety } & Levels of & \multicolumn{5}{|c|}{ Number of leaves palnt } \\
& IAA $(\mathrm{ppm})$ & $15 \mathrm{DAP}$ & $30 \mathrm{DAP}$ & $45 \mathrm{DAP}$ & $60 \mathrm{DAP}$ & 70 DAP \\
\cline { 3 - 7 } & 0 & $15.00 \mathrm{ab}$ & $31.67 \mathrm{~d}$ & $59.00 \mathrm{~b}$ & $60.67 \mathrm{~d}$ & $61.33 \mathrm{c}$ \\
\hline \multirow{3}{*}{$\begin{array}{c}\text { BARI } \\
\text { Oomato-7 }\end{array}$} & 100 & $15.33 \mathrm{ab}$ & $40.00 \mathrm{abc}$ & $70.33 \mathrm{a}$ & $72.00 \mathrm{ab}$ & $73.00 \mathrm{ab}$ \\
\cline { 2 - 7 } & 200 & $16.33 \mathrm{a}$ & $40.67 \mathrm{abc}$ & $69.33 \mathrm{a}$ & $71.00 \mathrm{~b}$ & $71.67 \mathrm{~b}$ \\
\hline \multirow{3}{*}{ Manik } & 0 & $15.67 \mathrm{ab}$ & $32.67 \mathrm{~d}$ & $60.33 \mathrm{~b}$ & $62.67 \mathrm{c}$ & $63.33 \mathrm{c}$ \\
\cline { 2 - 7 } & 100 & $16.33 \mathrm{a}$ & $39.67 \mathrm{bc}$ & $71.67 \mathrm{a}$ & $73.67 \mathrm{a}$ & $74.33 \mathrm{a}$ \\
\cline { 2 - 7 } & 200 & $16.33 \mathrm{a}$ & $41.67 \mathrm{a}$ & $70.33 \mathrm{a}$ & $72.00 \mathrm{ab}$ & $72.33 \mathrm{ab}$ \\
\hline \multirow{2}{*}{ Ratan } & 0 & $14.33 \mathrm{~b}$ & $31.67 \mathrm{~d}$ & $61.00 \mathrm{~b}$ & $61.67 \mathrm{~cd}$ & $62.33 \mathrm{c}$ \\
\cline { 2 - 7 } & 100 & $14.00 \mathrm{~b}$ & $39.33 \mathrm{c}$ & $71.67 \mathrm{a}$ & $73.00 \mathrm{ab}$ & $73.33 \mathrm{ab}$ \\
\cline { 2 - 7 } & 200 & $14.00 \mathrm{~b}$ & $41.33 \mathrm{ab}$ & $69.67 \mathrm{a}$ & $71.67 \mathrm{ab}$ & $72.00 \mathrm{ab}$ \\
\hline \multicolumn{2}{|c|}{$\mathrm{CV}(\%)$} & 6.67 & 2.72 & 2.38 & 1.54 & 1.91 \\
\hline
\end{tabular}

Values followed by the different letter(s) are significantly different from each other by DMRT at $5 \%$ level

\section{Number of branches plant ${ }^{-1}$}

The combined effect of IAA and tomato varieties on number of branches is presented in Table 3. From the results it was found that at 15 DAP the interaction effect of tomato varieties and various levels of IAA was insignificant, but it was significant at 30, 45, 60 and 70 DAP. At 15 DAP the maximum number of branches (4.00) was found in BARI Tomato-7 with 100 and 200 ppm IAA treated plots and Manik with 200 ppm IAA treated plots. The minimum number of branches showed by Ratan with 100 ppm IAA (3.33) treated plots. BARI Tomato-7 produced highest number of branches (11.00) with 100 ppm IAA treated plots followed by BARI Tomato- $7 \times 200 \mathrm{ppm}$ IAA (10.67) and Manik $\times 100$ ppm IAA (10.33), whereas the lowest number of branches was found by Ratan (6.00) under control condition which was followed by Manik (6.67) with 0 ppm IAA treated plots at 30 DAP. At 45 DAP BARI Tomato-7 produced highest number of branches (16.33) with $100 \mathrm{ppm}$ IAA treated plots followed by BARI Tomato$7 \times 200$ ppm IAA (15.67) and Manik $\times 100$ ppm IAA
(15.00), whereas the lowest number of branches was found by Manik (9.67) under control condition which was followed by Ratan (10.33) with 0 ppm IAA treated plots. At 60 DAP BARI Tomato-7 produced highest number of branches (17.33) with 100 ppm IAA treated plots followed by BARI Tomato-7×200 ppm IAA (16.67) and Manik $\times 100$ ppm IAA (16.00), whereas the lowest number of branches was found by Manik (10.00) under control condition which was followed by Ratan (11.00) with 0 ppm IAA treated plots. At 70 DAP BARI Tomato-7 produced highest number of branches (17.67) with 100 ppm IAA treated plots which was statistically similar with Manik and Ratan under 100 ppm IAA treated plots (16.66), whereas the lowest number of branches was found by Manik (10.33) which was followed by Ratan (11.33) and BARI Tomato-7 (12.33) with 0 ppm IAA treated plots. Prasad et al. (2013) also found that there was a linear increase in number of branches per plant with increasing level of $\mathrm{GA}_{3}$ and auxin (NAA).

Table 3. Interaction effect of IAA and varieties of tomato on number of branches at different days after planting (DAP)

\begin{tabular}{|c|c|c|c|c|c|c|}
\hline \multirow[t]{2}{*}{ Variety } & \multirow{2}{*}{$\begin{array}{l}\text { Levels of } \\
\text { IAA (ppm) }\end{array}$} & \multicolumn{5}{|c|}{ Number of Branches plant $^{-1}$} \\
\hline & & 15 DAP & 30 DAP & 45 DAP & 60 DAP & 70 DAP \\
\hline \multirow{3}{*}{$\begin{array}{c}\text { BARI } \\
\text { Tomato-7 }\end{array}$} & 0 & $3.67 \mathrm{a}$ & $7.33 \mathrm{~d}$ & $11.67 \mathrm{e}$ & $12.00 \mathrm{~d}$ & $12.33 \mathrm{~cd}$ \\
\hline & 100 & $4.00 \mathrm{a}$ & $11.00 \mathrm{a}$ & $16.33 \mathrm{a}$ & $17.33 \mathrm{a}$ & $17.67 \mathrm{a}$ \\
\hline & 200 & $4.00 \mathrm{a}$ & $10.67 \mathrm{a}$ & $15.67 \mathrm{ab}$ & $16.67 \mathrm{ab}$ & $17.00 \mathrm{a}$ \\
\hline \multirow[t]{3}{*}{ Manik } & 0 & $3.67 \mathrm{a}$ & $6.67 \mathrm{de}$ & $9.67 \mathrm{f}$ & $10.00 \mathrm{e}$ & $10.33 \mathrm{e}$ \\
\hline & 100 & $3.67 \mathrm{a}$ & $10.33 \mathrm{ab}$ & $15.00 \mathrm{bc}$ & $16.00 \mathrm{bc}$ & $16.66 \mathrm{a}$ \\
\hline & 200 & $4.00 \mathrm{a}$ & $9.67 \mathrm{~b}$ & $14.67 \mathrm{~cd}$ & $15.67 \mathrm{bc}$ & $16.00 \mathrm{ab}$ \\
\hline \multirow[t]{3}{*}{ Ratan } & 0 & $3.67 \mathrm{a}$ & $6.00 \mathrm{e}$ & $10.33 \mathrm{f}$ & $11.00 \mathrm{de}$ & $11.33 \mathrm{c}$ \\
\hline & 100 & $3.33 \mathrm{a}$ & $9.67 \mathrm{~b}$ & $14.67 \mathrm{~cd}$ & $16.00 \mathrm{bc}$ & $16.66 \mathrm{a}$ \\
\hline & 200 & $3.67 \mathrm{a}$ & $8.67 \mathrm{c}$ & $14.00 \mathrm{~d}$ & $15.33 \mathrm{c}$ & $16.00 \mathrm{ab}$ \\
\hline \multicolumn{2}{|c|}{$\mathrm{CV}(\%)$} & 12.47 & 4.40 & 3.01 & 4.39 & 3.80 \\
\hline
\end{tabular}

Values followed by the different letter(s) are significantly different from each other by DMRT at $5 \%$ level 


\section{First flower initiation}

The influence of IAA on first flower initiation of tomato varieties at different days after planting is shown in Table 4. The interaction effect of IAA and varieties on days required for first flower initiation of tomato was significant. From the results it was found that the maximum number of days required for first flowering by Ratan (38.67 days) at control condition which was followed by Manik (37.33 days) with 0 ppm IAA treated plots.
On the other hand, the minimum number of days required for first flower initiation by BARI Tomato-7 with 100 ppm IAA treated plots (31.33 days) followed by same variety with 200 ppm IAA (33.00 days). Singh and Singh (2005) reported that the initiation time of first flowering and first fruiting was significantly and highly increased by application of NAA which was agreed with the present result.

Table 4. Interaction effect of IAA and varieties of tomato on first flower initiation, $50 \%$ flowering initiation and fruit setting

\begin{tabular}{|c|c|c|c|c|}
\hline Variety & $\begin{array}{c}\text { Levels of IAA } \\
(\mathrm{ppm})\end{array}$ & $\begin{array}{c}\text { First flowering } \\
\text { initiation (Days) }\end{array}$ & 50\% flowering (Days) & $\begin{array}{c}\text { Fruit setting } \\
\text { (Days) }\end{array}$ \\
\hline \multirow{3}{*}{ BARI Tomato-7 } & 0 & $35.67 \mathrm{~cd}$ & $41.67 \mathrm{ab}$ & $43.67 \mathrm{a}$ \\
& 100 & $31.33 \mathrm{~g}$ & $37.33 \mathrm{e}$ & $39.33 \mathrm{f}$ \\
& 200 & $33.00 \mathrm{f}$ & $38.33 \mathrm{~d}$ & $40.33 \mathrm{de}$ \\
\hline \multirow{3}{*}{ Manik } & 0 & $37.33 \mathrm{~b}$ & $42.33 \mathrm{ab}$ & $41.67 \mathrm{bc}$ \\
& 100 & $34.00 \mathrm{ef}$ & $38.67 \mathrm{~d}$ & $39.67 \mathrm{ef}$ \\
& 200 & $36.00 \mathrm{c}$ & $41.33 \mathrm{~b}$ & $41.00 \mathrm{~cd}$ \\
\hline \multirow{2}{*}{ Ratan } & 0 & $38.67 \mathrm{a}$ & $42.67 \mathrm{a}$ & $42.00 \mathrm{~b}$ \\
& 100 & $34.67 \mathrm{de}$ & $39.67 \mathrm{c}$ & $39.00 \mathrm{f}$ \\
& 200 & $37.33 \mathrm{~b}$ & $42.33 \mathrm{ab}$ & $41.33 \mathrm{bc}$ \\
\hline
\end{tabular}

Values followed by the different letter(s) are significantly different from each other by DMRT at $5 \%$ level

\section{Fifty percent flowering}

The combined effect of IAA and varieties on days required for $50 \%$ flowering of tomato was significant which is presented in Table 4 . From the results it was found that the highest number of days required for $50 \%$ flowering by Ratan (42.67 days) at control condition which was followed by Manik (42.33 days) with o ppm IAA treated plots. On the other hand, the lowest number of days required for $50 \%$ flowering by BARI Tomato-7 with 100 ppm IAA treated plots (37.33 days) followed by Manik with 100 ppm IAA (38.67 days).

\section{Fruit setting}

The combined effect of IAA and tomato varieties on days required for fruit setting of tomato was significant which is presented in Table 4 . From the results, it was found that the all the varieties required higher number of days for fruit setting under control condition than IAA treated plots. The highest number of days required for fruit setting was found by BARI Tomato 7 (43.67 days) with 0 ppm IAA treated plots, which was followed by Ratan (42.00 days) and Manik (41.67 days) with o ppm IAA treated plots. On the other hand, the lowest number of days required for fruit setting was showed by Ratan (39.00) with 100 ppm IAA treated plots which was statistically similar with BARI Tomato-7 $\times 100$ ppm IAA (39.33 days) and Manik $\times 100$ ppm IAA (39.67 days). Gaba et al. (1999) found same trend of result in tomato by application of plant growth regulator.

\section{Fruits cluster plant ${ }^{-1}$}

The interaction effect of IAA and tomato varieties on number of fruit cluster plant ${ }^{-1}$ of tomato was significant and it is presented in Table 5. From the results, it was found that number of fruit cluster plant $^{-1}$ was increased with the increment of concentration of indole acetic acid (IAA). the maximum number of fruit cluster plant $^{-1}$ was produced by BARI Tomato-7 (8.00) with 100 ppm IAA treated plots which was followed by BARI Tomato-7 $\times 200$ ppm IAA, Manik $\times 100$ ppm IAA and Manik $\times 200$ ppm IAA; all of these three treatments combination produced 7.67 number of fruit cluster plant ${ }^{-1}$. On the other hand, Manik $\times 0$ ppm IAA treated plots produced the lowest number of fruit cluster plant ${ }^{-1}$ (6.67) which was followed by Manik $\times 0$ ppm IAA and Ratan $\times 200$ ppm IAA treated plots (7.00).

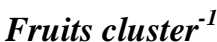

The interaction effect of IAA and tomato varieties on number of fruit cluster ${ }^{-1}$ was significant and it is presented in Table 5. From the results, it was found that number of fruit cluster ${ }^{-1}$ was increased with $100 \mathrm{ppm}$ indole acetic acid (IAA) than $200 \mathrm{ppm}$ IAA treated plots. the maximum number of fruit cluster $^{-1}$ was produced by BARI Tomato-7 (4.00) with 100 ppm IAA treated plots which was followed by BARI Tomato-7×200 ppm IAA, Manik $\times 100$ ppm IAA and Ratan $\times 100$ ppm IAA; all of these three treatments combination produced 3.67 number of fruit cluster ${ }^{-1}$. On the other hand, Manik $\times 0$ ppm IAA and Ratan $\times 0$ ppm IAA treated plots produced the lowest number of fruit cluster ${ }^{-1}$ 
(3.00) which was followed by Ratan $\times 200 \mathrm{ppm}$ IAA treated plots (3.33). Hossain (1974) also found that the application of plant growth regulator increased the number of fruit per cluster. This results also supported by Prasad et al. (2013).

\section{Fruits plant ${ }^{-1}$}

The interaction effect of IAA and tomato varieties on number of fruit plant ${ }^{-1}$ of tomato was significant and it is presented in Table 5. From the results, it was found that number of fruit plant ${ }^{-1}$ was increased in $100 \mathrm{ppm}$ indole acetic acid (IAA) compared to 200 ppm IAA treated plots and control condition. the maximum number of fruit plant $^{-1}$ was produced by BARI Tomato-7 with 100 ppm IAA treated plots (32.67) which was followed by BARI
Tomato-7 $\times 200$ ppm IAA (28.33) and Manik $\times$ 100 ppm IAA (27.67). On the other hand, Ratan $\times$ 0 ppm IAA treated plots produced the lowest number of fruit plant ${ }^{-1}$ (20.00) which was statistically at par with Manik $\times 0$ ppm IAA combination (21.00). Hossain (1974) and Prasad et al. (2013).also found that the application of plant growth regulator increased the number of fruit per plant. Gaba et al. (1999) found same trend of result in tomato by application of plant growth regulator. Singh and Singh (2005) reported that the initiation time of fruit setting was significantly and highly increased by application of NAA which was agreed with the present result.

Table 5. Interaction effect of IAA and Varieties of tomato on fruit cluster plant ${ }^{-1}$, fruit cluster ${ }^{-1}$, fruit plant ${ }^{-1}$, length of fruit, diameter of fruit at harvest

\begin{tabular}{|c|c|c|c|c|c|c|}
\hline Vareity & $\begin{array}{c}\text { Levels of } \\
\text { IAA }(\mathrm{ppm})\end{array}$ & $\begin{array}{c}\text { No. of fruit } \\
\text { cluster plant }^{-1}\end{array}$ & $\begin{array}{c}\text { No. of fruit } \\
\text { cluster }^{-1}\end{array}$ & $\begin{array}{c}\text { No. of fruit } \\
\text { plant }^{-1}\end{array}$ & $\begin{array}{c}\text { Length of } \\
\text { fruit }(\mathrm{cm})\end{array}$ & $\begin{array}{c}\text { Diameter of } \\
\text { fruit }(\mathrm{cm})\end{array}$ \\
\hline \multirow{3}{*}{$\begin{array}{c}\text { BARI } \\
\text { Tomato-7 }\end{array}$} & 0 & $7.33 \mathrm{~b}$ & $3.67 \mathrm{ab}$ & $26.67 \mathrm{~cd}$ & $4.72 \mathrm{e}$ & $4.00 \mathrm{ab}$ \\
\cline { 2 - 7 } & 100 & $8.00 \mathrm{a}$ & $4.00 \mathrm{a}$ & $32.67 \mathrm{a}$ & $5.19 \mathrm{a}$ & $4.28 \mathrm{ab}$ \\
\cline { 2 - 7 } & 200 & $7.67 \mathrm{ab}$ & $3.67 \mathrm{ab}$ & $28.33 \mathrm{~b}$ & $5.10 \mathrm{ab}$ & $4.13 \mathrm{ab}$ \\
\hline \multirow{3}{*}{ Manik } & 0 & $7.00 \mathrm{bc}$ & $3.00 \mathrm{~b}$ & $21.00 \mathrm{f}$ & $4.57 \mathrm{f}$ & $3.90 \mathrm{ab}$ \\
\cline { 2 - 7 } & 100 & $7.67 \mathrm{ab}$ & $3.67 \mathrm{ab}$ & $27.67 \mathrm{bc}$ & $5.10 \mathrm{ab}$ & $4.15 \mathrm{ab}$ \\
\cline { 2 - 7 } & 200 & $7.67 \mathrm{ab}$ & $3.33 \mathrm{ab}$ & $25.67 \mathrm{~d}$ & $5.03 \mathrm{bc}$ & $4.10 \mathrm{ab}$ \\
\hline \multirow{2}{*}{ Ratan } & 0 & $6.67 \mathrm{c}$ & $3.00 \mathrm{~b}$ & $20.00 \mathrm{f}$ & $4.40 \mathrm{~g}$ & $3.83 \mathrm{~b}$ \\
\cline { 2 - 7 } & 100 & $7.33 \mathrm{~b}$ & $3.67 \mathrm{ab}$ & $26.67 \mathrm{~cd}$ & $4.93 \mathrm{~cd}$ & $4.09 \mathrm{ab}$ \\
\cline { 2 - 7 } & 200 & $7.00 \mathrm{bc}$ & $3.33 \mathrm{ab}$ & $23.33 \mathrm{e}$ & $4.83 \mathrm{de}$ & $4.29 \mathrm{a}$ \\
\hline \multicolumn{2}{|c|}{$\mathrm{CV}(\%)$} & 4.71 & 9.97 & 3.51 & 1.48 & 5.55 \\
\hline
\end{tabular}

Values followed by the different letter(s) are significantly different from each other by DMRT at 5\% level.

\section{Length of fruit}

The combined effect of IAA and tomato varieties on length of fruit of tomato was significant and it is presented in Table 5. From the results, it was found that the IAA treated plots produced larger size fruit than control condition and again 100 ppm IAA treated plots produced larger size fruit compared to 200 ppm IAA treated plots. BARI Tomato-7 with $100 \mathrm{ppm}$ IAA treated plots $(5.19 \mathrm{~cm})$ was showed the largest fruit which was followed by the combination of BARI Tomato-7 $\times 200$ ppm IAA and Manik $\times 100$ ppm IAA and it was $5.10 \mathrm{~cm}$ in length. On the other hand, the lowest length of fruit was produced by Manik with 0 ppm IAA treated plots $(4.57 \mathrm{~cm})$ which was followed by the treatment combinations of BARI Tomato-7 $\times 0$ ppm IAA $(4.72 \mathrm{~cm})$ and Ratan $\times 200$ ppm IAA $(4.83 \mathrm{~cm})$. Abdel et al. (1996) showed that due to application of IAA and $\mathrm{GA}_{3}$ increased flux seed yield due to increased length of fruit, this result also supported by Adam et al. (2011) who also found that the naphthalene acetic acid increased yield of two varieties of rice (Oryza sativa L.) for increasing length of caryopsis.

\section{Diameter of fruit}

The interaction effect of IAA and tomato varieties on diameter of fruit of tomato was significant and it is presented in Table 5. From the results, it was found that the IAA treated plots produced larger size fruit than control condition and 100 ppm IAA treated plots produced slightly larger size fruit compared to 200 ppm IAA treated plots. Ratan with 200 ppm IAA treated plots was showed the largest fruit diameter $(4.29 \mathrm{~cm})$ which was followed by BARI Tomato-7 with 100 ppm IAA (4.28) treated plots and Manik with 100 ppm IAA $(4.15 \mathrm{~cm})$ treated plots. On the other hand, the lowest diameter of fruit was attained by Ratan $(3.83 \mathrm{~cm})$ at control condition followed by Manik with 0 ppm IAA treated plots (3.90). Abdel et al. (1996), Adam et al. (2011) and Singh and Singh (2005) showed that due to application of IAA and $\mathrm{GA}_{3}$ the yield of tomato increased due to increasing the length and diameter of fruit.

\section{Individual fruit weight}

The interaction effect of IAA and varieties on weight tomato ${ }^{-1}$ was insignificant and it is presented in Table 6. From the results, it was found that the highest single fruit weight showed by BARI Tomato-7 with 100 ppm IAA (82.00 g) which was statistically at par with BARI Tomato-7 with 200 ppm IAA $(81.67 \mathrm{~g})$ and the treatment combinations of BARI Tomato- $7 \times 0$ ppm IAA, Manik $\times 100 \mathrm{ppm}$ 
IAA, Ratan $\times 100$ ppm IAA and Ratan $\times 200$ ppm IAA, where single fruit weight was $81.00 \mathrm{~g}$. On the other hand, the lowest single fruit weight $(80.50 \mathrm{~g})$ produced by Manik with 200 ppm IAA , Ratan with 0 ppm IAA treated plots followed by Manik
$(80.53 \mathrm{~g})$ at control condition. Sanyal (1995) and Prasad et al. (2013) also found that application of plant growth regulator at vegetative stage increased fruit size which increased individual fruit weight of tomato.

Table 6. Interaction effect of IAA and varieties of tomato on weight tomato ${ }^{-1}$, yield plant ${ }^{-1}$, yield plot $^{-1}$ and yield hectare $^{-1}$ at harvest

\begin{tabular}{|c|c|c|c|c|c|}
\hline \multirow{2}{*}{ Vareity } & $\begin{array}{c}\text { Levels of IAA } \\
(\mathrm{ppm})\end{array}$ & Weight tomato $^{-1}(\mathrm{~g})$ & Yield plant $^{-1}(\mathrm{~kg})$ & $\begin{array}{c}\text { Yield } \\
\text { plot }^{-1}(\mathrm{~kg})\end{array}$ & Yield hectare $^{-1}(\mathrm{t})$ \\
\hline \multirow{3}{*}{ BARI Tomato-7 } & 0 & $81.00 \mathrm{a}$ & $2.16 \mathrm{~cd}$ & $34.51 \mathrm{bcd}$ & $86.27 \mathrm{~cd}$ \\
\cline { 2 - 6 } & 100 & $82.00 \mathrm{a}$ & $2.62 \mathrm{a}$ & $41.92 \mathrm{a}$ & $104.80 \mathrm{a}$ \\
\cline { 2 - 6 } & 200 & $81.67 \mathrm{a}$ & $2.31 \mathrm{~b}$ & $36.91 \mathrm{~b}$ & $90.93 \mathrm{~b}$ \\
\hline \multirow{3}{*}{ Manik } & 0 & $80.53 \mathrm{a}$ & $1.70 \mathrm{f}$ & $25.20 \mathrm{f}$ & $68.00 \mathrm{f}$ \\
\cline { 2 - 6 } & 100 & $81.00 \mathrm{a}$ & $2.24 \mathrm{bc}$ & $35.99 \mathrm{bc}$ & $89.47 \mathrm{bc}$ \\
\cline { 2 - 6 } & 200 & $80.50 \mathrm{a}$ & $2.07 \mathrm{~d}$ & $33.01 \mathrm{~d}$ & $82.53 \mathrm{~d}$ \\
\hline \multirow{3}{*}{ Ratan } & 0 & $80.50 \mathrm{a}$ & $1.61 \mathrm{f}$ & $25.81 \mathrm{f}$ & $64.53 \mathrm{f}$ \\
\cline { 2 - 6 } & 100 & $81.00 \mathrm{a}$ & $2.15 \mathrm{~cd}$ & $34.11 \mathrm{~cd}$ & $86.12 \mathrm{~cd}$ \\
\hline \multicolumn{2}{|r|}{$\mathrm{CV}(\%)$} & $81.00 \mathrm{a}$ & $1.90 \mathrm{e}$ & $30.28 \mathrm{e}$ & $76.00 \mathrm{e}$ \\
\hline \multicolumn{2}{|c|}{$\mathrm{C}$} & 1.03 & 2.85 & 4.20 & 2.87 \\
\hline
\end{tabular}

Values followed by the different letter(s) are significantly different from each other by DMRT at $5 \%$ level.

\section{Yield plant ${ }^{-1}$}

The influence of IAA on yield plant $^{-1}$ of tomato varieties at different days after planting is shown in Table 6. From the significant interaction effect of IAA and tomato varieties on yield plant $^{-1}$ it was found that the highest yield plant $^{-1}$ showed by BARI Tomato-7 with 100 ppm IAA (2.62 kg) which was followed by BARI Tomato-7 with 200 ppm IAA and Manik with 100 ppm IAA treated plots (2.31 and $2.24 \mathrm{~kg}$, respectively). On the other hand, the lowest yield plant $^{-1}$ of tomato was produced by Ratan with 0 ppm IAA (1.61 kg) followed by Manik $(1.70 \mathrm{~kg})$ at control condition and Ratan with 200 ppm IAA treated plots (1.90 $\mathrm{kg}$ ). Some researchers also showed that auxin increased yield of tomato. Hayat et al. (2001) observed that all the phytohormones, except ABA, improved the vegetative growth and seed yield at harvest over the control and the order of response to various hormones was $\mathrm{HBR}>\mathrm{GA}_{3}>\mathrm{IAA}>$ $\mathrm{KIN}>$ control > ABA.

\section{Yield plot ${ }^{-1}$}

The interaction effect of IAA and varieties on yield plot $^{-1}$ of tomato was significant and it is presented in Table 6. From the results, it was found that the highest yield plot $^{-1}$ showed by BARI Tomato-7 with 100 ppm IAA (41.92 kg) which was followed by BARI Tomato-7 with 200 ppm IAA and Manik with $100 \mathrm{ppm}$ IAA (36.91 and $35.99 \mathrm{~kg}$, respectively). On the other hand, the lowest yield plot $^{-1}$ of tomato was recorded from Manik at control condition $(25.20 \mathrm{~kg})$ followed by Ratan with 0 ppm IAA treated plots $(25.81 \mathrm{~kg})$.

\section{Yield hectare $^{-1}$}

The influence of IAA on yield hectare ${ }^{-1}$ of tomato varieties at different days after planting is shown in Table 6. The combined effect of IAA and varieties on yield hectare ${ }^{-1}$ of tomato was significant. From the results, it was found that the highest yield hectare $^{-1}$ showed by BARI Tomato-7 with $100 \mathrm{ppm}$ IAA $(104.80 \mathrm{t})$ which was followed by BARI Tomato-7 with 200 ppm IAA treated plots and Manik with 100 ppm IAA treated plots (90.93 and $89.47 \mathrm{t}$, respectively). On the other hand, the lowest yield hectare ${ }^{-1}$ of tomato was produced by Ratan with 0 ppm IAA $(64.53 \mathrm{t})$ followed by Manik at control condition $(68.00 \mathrm{t})$ and Ratan with $200 \mathrm{ppm}$ IAA treated plots $(76.00 \mathrm{t})$. Application of plant growth regulator significantly increased the yield of crops. Abdel et al. (1996) showed that due to application of IAA and $\mathrm{GA}_{3}$ increased flux seed yield and their metabolic constituents. Adam et al. (2011) also found that the naphthalene acetic acid increased yield of two varieties of rice (Oryza sativa L.). Sanyal (1995) also found that application of plant growth regulator at vegetative stage increased fruit yield per hectare of tomato.

\section{Conclusions}

From the overall results it may be concluded that IAA treated plots showed better performance for growth parameters and yield compared to control condition. Therefore, 100 ppm IAA was more suitable than the 200 ppm IAA for tomato cultivation. Among the treatment combinations, BARI Tomato-7 with 100 ppm IAA was superior followed by Manik with 100 ppm IAA and Ratan with 0 ppm IAA was inferior followed by Manik with 0 ppm IAA and BARI Tomato-7 with 0 ppm IAA. BARI Tomato-7 with 200 ppm IAA, Manik with 200 ppm IAA and Ratan with 200 ppm IAA treated plots showed the intermediate results for yield and yield attributing characteristics. 


\section{References}

Abdel, G. B. A.; El-Shourbagy, M. N. and ElNaggar, R. A. 1996. Effect of IAA and $\mathrm{GA}_{3}$ on flux seed yield and their metabolic constituents. Egyptian J. Bot., 35: 1-6.

Adam, A. Golam M. M, and Jahan Nargis. 2011. Effects of naphthalene acetic acid on yield attributes and yield of two varieties of rice (Oryza sativa 1.). Bangladesh J. Bot., 40(1): 97-100.

Egamberdieva, D. 2009. Alleviation of salt stress by plant growth regulators and IAA producing bacteria in wheat. Acta Physiol. Plant., 31: 861-864.

Gaba, G.M., Oben, G. and Garcell R. 1999. Effect of GA3 on morpho-physiological characters and yield of kidney beans. J. Agron. Crop Sci. 160(2): 91-101.

Gomez, K.A. and Gomez, A.A. 1984. Statistical Procedures for Agricultural Research. John Willey and Sons, New York. pp. 397-411.

Hayat, S., Ahmad, A. Mobin, M., Fariduddin, Q., Azam, Z.M. 2001. Carbonic Anhydrase, Photosynthesis, and Seed Yield in Tomato Plants Treated with Phytohormones. Photosynthetica, 39(1): 111-114.

Hossain, M. A. E. 1974. Studies on the effect of paracyclrophonexy acetic acid and GA3 on the production of tomato. M.Sc. Thesis, Dept. Hort. BAU, Myminsingh.

Mondal, M. M. A., Akter, M. B. and. Razzaque, A. H. M. 2011. Effect of seasonal seeds on growth and yield in tomato genotypes. Int. J. Expt. Agric., 2 (1): 12-16.
Nahar, B. S. and Ikeda, T. 2002. Effect of different concentrations of figaron on production and abscission of reproductive organs, growth and yield in soybean. Field Crop Res., 78: 41-50.

Prasad, R. N, Singh, S. K., Yadava, R. B. and Chaurasia, S. N. S. 2013. Effect of GA3 and NAA on growth and yield of tomato. Vegetable Science, 40 (2): 195-197.

Saimbhi, M. S. 1993. Growth regulators on vegetable crops. In: K. L. Chadha and G. Kallo (eds.). Advances in Horticulture, vol. 6 (I). Malhotra Publishing House, New Delhi, India. pp. 619-642.

Sanyal, D., Kar, P. L. and.Longkumar, M. 1995. Effect of growth regulators on the physiochemical composition of tomato. Adv.

Singh, R. and Singh, L. 2005. Effect of plant growth regulators and micronutrient mixtures on growth and yield of tomato. Allahabad. India. Bioved. 16(1/2): 101-105

Ray, P. K. 2014. Study on morphological characteristics and yield performance of mustard under the influence of plant growth regulator (IAA). MS thesis, Hajee Mohammad Danesh Science and Technology University, Dinajpur. p.48.

Rout, G. R. 2006. Effects of Auxins on adventitious root development from single node cutting of Camellia sinensis (L.) Kuntze and associated biochemical changes. Plant Growth Regul., 48: 111-117. 